Trinity University

Digital Commons @ Trinity

Modern Languages and Literatures Faculty

Research

Modern Languages and Literatures Department

2016

\title{
The Cornelian Ethics of Flight and The Case of Horace
}

Nina Ekstein

Trinity University, nekstein@trinity.edu

Follow this and additional works at: https://digitalcommons.trinity.edu/mll_faculty

Part of the Modern Languages Commons

\section{Repository Citation}

Ekstein, N. (2016). The Cornelian ethics of flight and the case of Horace. Romance Notes, 56(3), 485-493. doi: $10.1353 /$ rmc. 2016.0050

This Article is brought to you for free and open access by the Modern Languages and Literatures Department at Digital Commons @ Trinity. It has been accepted for inclusion in Modern Languages and Literatures Faculty Research by an authorized administrator of Digital Commons @ Trinity. For more information, please contact jcostanz@trinity.edu. 


\title{
THE CORNELIAN ETHICS OF FLIGHT AND THE CASE OF HORACE
}

\author{
NINA EKSTEIN
}

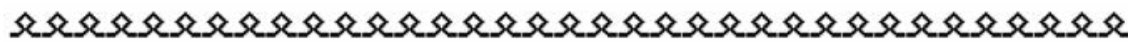

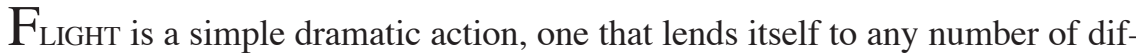
ferent plots. Its implied movement can be represented on stage or merely recounted. So common is it that the words fuite and fuir appear in every one of Corneille's 32 plays, from as infrequently as twice to as many as 32 times. $^{1}$ The two terms belong to a broad semantic network including retraite, éviter, dérober, échapper, partir, quitter, abandonner, but differ in their suggestion of abrupt, precipitous movement as well as the element of fear implied. Furetière begins his definition of fuir with "Tascher d'éviter un péril en s'en éloignant à force de jambes." The next sentence, however, immediately ties the term to issues of morality: "Les braves aiment mieux périr que fuir d'une bataille." Thus a common, if at times startling, action has inherent ethical ramifications. Indeed, so central is morality to flight that a careful examination of the words' occurrences throughout Corneille's reuvre allows the construction of a Cornelian ethics of flight, one whose rules are applied consistently throughout his plays. I propose to develop such a Cornelian ethics of flight and to examine a sole, glaring exception: Horace, a figure whose ambiguity has given rise to both diverse and contradictory interpretations. ${ }^{2}$

The rules governing flight are not overly complex. Two issues are central to this ethics: gender and heroism. As we shall see, the rules are often not the same for men and for women. As far as heroism is concerned, itself a gendered concept, there is a deep-rooted antagonism between heroism and flight.

First and foremost, it is morally unacceptable for a male to flee a confrontation with another male. This preeminent rule is central to any notion of

${ }^{1}$ There are a total of 313 uses of fuite or a form of fuir in Corneille's theater; the average per play is 8.5 occurrences. The highest frequency is found in Médée (32), Horace (19), Clitandre (18), La Galerie du Palais (17), L'Illusion comique (17), and La Mort de Pompée (17).

${ }^{2}$ See McClure (146-47). 
heroism and concerns only men. Flight is completely dishonorable in such circumstances, (as when Phinée flees Persée in Andromède [5.5] or when Dorante hastily abandons marriage, home, and father in the action bridging Le Menteur and La Suite du Menteur). It follows logically then that one male forcing another male to flee constitutes an essentially heroic action (such as Rodrigue's prowess causing the Mores to flee in Le Cid [4.3]). In a similar vein, standing one's ground and refusing to flee is coded positively (as when Polyeucte rejects Néarque's advice to flee the site of the Roman altar [Polyeucte 2.6] or when Cinna refuses Émilie's entreaties to flee Auguste's summons at the end of the first act of Cinna). Corneille's men who flee confrontation deserve to be pursued (for example, Pompée's allies, as César tells Cléopâtre: "En quelques lieux qu'on fuie, il me faut y courir" [4.3.1331]). ${ }^{3}$ Finally, returning after fleeing (as do Prusias and Flaminius in Nicomède [5.8] and Maxime in Cinna [5.3]) makes partial amends for the original shameful flight.

Second, while fuite is dishonorable, fleeing a negative is coded positively. Such flight is largely, but not exclusively, a female domain. Sophonisbe will do anything to "fuir l'indignité" of being brought to Rome as a spoil of war (Sophonisbe 3.6.1088); Héraclius and Pulchérie flee "à l'égal de la mort" a union between them which they know to be incestuous (Héraclius 1.1.76), and Camille urges the eponymous Othon to flee in order to avoid attack (4.6.1470). Alice Rathé notes an interesting all-male variant of flight from a negative: Clindor in L'Illusion comique, Dorante in La Suite du Menteur, and Don Sanche in Don Sanche d'Aragon substitute fuite for parricide ("Tentation" 320). Whether out of anger (Clindor), revolt (Dorante), or shame (Don Sanche), the men bolt instead of acting on their feelings toward their father more directly. ${ }^{4}$

Third, no stigma is attached to fleeing a confrontation if the one who flees is a woman. Cornélie flees her husband Pompée's killers, as Pompée had urged before being killed ("Songe à prendre la fuite afin de me venger" [2.2.472]);

\footnotetext{
${ }^{3}$ Indeed, fuite / fuir and poursuite / poursuit are rhymed sixteen times in Corneille's theater, either as a substantive or as a verb. For example, when in La Mort de Pompée Cornélie is reported to be fleeing after her husband has been assassinated, Achorée says, "elle fuit, / Mais avec six vaisseaux un des miens la poursuit" (3.1.760-61). Similarly the two words are linked in Phorbas's récit of the confrontation between Phinée and Persée in Andromède: "J'entends Phinée enfin qui lui [à Persée] demande grâce. / 'Perfide, il n'est plus temps', lui dit Persée. Il fuit; / J'entends comme à grands pas ce vainqueur le poursuit" (5.5.1688-90).

${ }^{4}$ Of course what constitutes a negative is a subjective judgment: both Néarque and Polyeucte believe that Pauline is detrimental to Polyeucte's new-found faith (Néarque: "Fuyez un ennemi [Pauline] qui sait votre défaut" [1.1.104]; Polyeucte: “ce n'est qu'en fuyant que j'y puis résister" [1.2.124]). Needless to say, Pauline would view the situation quite differently.
} 
Didyme instructs Théodore to flee the brothel ("Fuyez sous mon habit," [Théodore 4.5.1439)]; and the dying king of Castille told his wife Léonor, "Fuyez dans la Castille" (Don Sanche d'Aragon 4.1.1145). It is clear that women are not under the same ethical onus as men when it comes to flight.

The fourth and final rule pertaining to fuite in Corneille's theater complicates matters considerably: both men and women may flee a confrontation without stigma when it involves a member of the opposite sex to whom one has a sentimental attachment. ${ }^{5}$ There is a considerable amount of flight of this sort in Corneille's comedies, particularly the early ones: it constitutes both a staple action (Lysandre laments his beloved's hasty departure in $L a$ Galerie du Palais: "Célidée, ah tu fuis! tu fuis donc" [2.7.649]) and a conventional metaphor (Philiste in La Veuve describes his attitude towards love: "je fuis ma guérison" [2.1.430]). The rule concerning sentimental flight extends to the tragedies and other serious plays as well. Dircé flees her beloved Thésée who begs her not to die for her people (Oedipe 2.4.773-74); we are told that Attila flees Ildione because of his feelings for her: "il en parle avec joie, et fuit à lui parler" (Attila 2.1.431); and Eurydice wonders, if indeed Suréna loves her, "pourquoi fuit-il mes yeux?" (Suréna 1.2.235). This fourth rule is not as clear-cut, however, as the others. If this category of flight involves a male character motivated by change - the choice to abandon one love object for another - then it is almost as reprehensible as fleeing confrontation with another male. Rodelinde holds Grimoald in contempt for his change from Eduïge to herself, calling him "un Prince qui vous fuit" (Pertharite 1.2.206) and in La Toison d'or Jason admits having fled his relationship with Hypsipyle (3.3.1223). In such cases we have little sympathy for the fleeing male.

Outside of these carefully circumscribed exceptions, flight is strongly coded as pejorative throughout Corneille's theater. The rules described above carve out a space for morally acceptable flight, but it is limited and primarily assigned to women. Furthermore, male heroism has no place in the act of fleeing a negative or a woman. Indeed, fuite and lâcheté are often linked implicitly and even at times explicitly, as when Émilie rebuffs Maxime's request that she flee with him: "Cesse de fuir en lâche un glorieux trépas" (Cinna 4.5.1355).

The rules governing flight are applied consistently throughout Corneille's theater with one intriguing exception, Horace. Before examining his case, it

${ }^{5}$ Joseph Harris notes that "whereas fleeing men, even one's enemies, compromises one's virility, fleeing women is an appropriate and even salutary response given the threat posed by their insidious, infectious tears" (169). 
is worth considering the two plays that immediately precede Horace in Corneille's auvre. If we contrast L'Illusion comique's Matamore with Rodrigue in Le Cid, it is clear that fuite in a situation of confrontation between two males is indeed the very antithesis of Cornelian heroism. Matamore, a perfect parody of the heroic figure, flees at the slightest sign of a threat, in marked contrast to his claims to be fearless. ${ }^{6}$ Rodrigue, the quintessential Cornelian hero, flees neither the Count nor even Chimène, but instead forces the Moors to flee. Thus at the very moment when Corneille establishes his legendary notion of heroism (1636-1637), fuite and heroism are enacted on stage and set out as mutually exclusive. The playwright's next work is Horace (1640). While this tragedy explicitly insists upon the same set of rules governing flight and its relation to heroism as the earlier (as well as the subsequent) plays, Horace's actions nonetheless call into question that relationship and furthermore problematize the notion of fuite.

Horace and his two brothers are chosen to represent Rome while the three Curiace brothers act on behalf of Alba in a battle for control over the two kingdoms. The combat occurs offstage during the latter part of the third act. The three Curiaces are all injured and two Horace brothers are dead when the third Horace, who remains unscathed, flees the scene. Julie, the eyewitness, is categorical: "Près d'être enfermé d'eux [the three Curiaces], sa fuite [Horace's] l'a sauvé" (3.6.1005). The implications are clear: Horace has acted to save himself. The elder Horace's reaction of horror and filicidal rage that is blasted across three consecutive scenes (3.6-4.2) reinforces the moral condemnation generated by Horace's flight. However, as Valère soon explains, the flight was a military tactic enabling Horace to divide and then best his enemies one by one. In a paradoxical formulation typical of Corneille, Valère asserts, "Il fuit pour mieux combattre" (4.2.1107) and pronounces, "La fuite est glorieuse en cette occasion" (4.2.1085). In light of the triumphant outcome, Valère simply brushes aside the moral problem of flight. Indeed Max Vernet reads the scene as the clash between an old system of values represented by the elder Horace, in which flight from battle is universally inexcusable, and a new system instituted by Horace (31). While Horace's flight sets up a moment of pleasurable surprise for the audience and although Vernet's argument is an intriguing one in a play that deals with a major new turn in Roman history, I nonetheless find it difficult to accept

${ }^{6}$ Matamore runs away from all confrontations, loud noises, and threats of beatings from valets. He finally takes flight from the stage and the play itself in act 4 scene 4 of L'Illusion comique when Isabelle questions him a bit closely about his flight to her attic where he has been living for several days. 
Horace's flight as heroic. ${ }^{7}$ The action of flight from male confrontation is coded so pejoratively throughout Corneille's theater, both before and after, that it is problematic to dissociate such an act from its customary connotations. In Rathé's terms, "[d]ans l'oeuvre de Corneille, fuir est toujours infâmant pour un guerrier" (Reine 80). Furthermore, Valère explicitly describes Horace's flight as a ruse ("cette prompte ruse," [4.2.1107]), another term that Corneille in no way associates with heroism.

Given the explicit focus on flight, ruse, and victory, Horace's conduct illustrates the Machiavellian concept of the ends justifying the means. Whether those ends are good or not is, however, a matter of subjective perspective (see note 4). Indeed, the women (Camille and Sabine) contest Valère's praise of Horace's flight. The questionable nature of Horace's tactic is further highlighted by the fact that his ends (heroic victory over Albe) are so blatantly opposed to his means (flight). Horace's great heroic moment is thus based on using an inherently dishonorable action to trick his opponents. ${ }^{8}$ Further irony is introduced by the fact that Horace alone was eager for this battle, whereas almost everyone else in both the Roman and Alban camps was horrified by the idea of sending two sets of brothers-in-law into battle against each other. Horace does not flee the prospect of such an encounter; instead he physically flees his brothers-in-law.

Tiphaine Karsenti and Alain Brunn contrast Horace's famous flight in battle with another instance in act IV in which he flees his wife Sabine and her demands that he kill her. "À quel point ma vertu devient-elle réduite," Horace exclaims, "Rien ne la saurait plus garantir que la fuite" (4.7.1395-96). While it is legitimate for a man to flee a woman to whom he is attached, Horace does not seem entirely successful in his flight: his "vertu" has already been "réduite." Karsenti and Brunn note the superfluity of this scene (4.7) to the play's action and focus on the paradoxical contrast between the two acts of flight: "l'une

7 Vernet's interpretation is undermined by the fact that nowhere else in Corneille's theater do we find any suggestion of such an opposition between old and new values in the context of flight.

8 David Maskell views Horace's flight as a "temporary lapse into female role-playing," based on Corneille's statement in his 1660 Examen of Horace attributing to women, in this case Camille, a propensity to flee the threat of death ("la frayeur si naturelle au sexe lui doit faire prendre la fuite") (276). He goes on to discuss how Horace reasserts his masculinity through killing.

9 In fact Horace fled Sabine earlier in act 2, scene 6 when she proposed that either her husband Horace or her brother Curiace kill her in order to legitimize the armed engagement between them. The ensuing diminishment of the men is similar to what we find above in act 4, scene 7. Indeed, in the earlier instance, Sabine comments to Curiace and Horace: "Vous poussez des soupirs, vos visages pâlissent! / Quelle peur vous saisit? sont-ce là ces grands cœurs, / Ces Héros qu'Albe et Rome ont pris pour défenseurs?" (2.6.664-66). The elder Horace hurries onstage to save the young men by urging them to flee: "ce n'est qu'en fuyant qu'on pare de tels coups" (2.7.685). 
actualise la fuite face à une femme aimée; l'autre, celle face à l'ennemi" (211). Incongruously, in their view, the legitimate flight from a woman leads to diminishment while the shameful flight from battle leads to glory (210-11).

I read the situation somewhat differently than do Karesenti and Brunn, and not merely because I question whether Horace's flight was "glorieuse en cette occasion" (4.2.1085), as Valère puts it. In fact there is a third instance of fuite in the same act. Between the descriptions of Horace's fuite from the three Curiace brothers and that of his flight from his wife's disturbing demands is Camille's flight from the stage when Horace draws his sword against her (4.5). Camille, verbally attacking first Horace and then Rome, provokes her brother to uncontrollable rage. The stage direction makes the action clear: "Horace, mettant la main à l'épée, et poursuivant sa soeur qui s'enfuit." Horace is not the one fleeing a confrontation this time; indeed he takes the active counter-position and pursues. The outcome, however, is the same as in the first instance. Horace kills in singular and unequal combat. I say 'unequal' because each of the Curiace brothers was already injured and because Camille is an unarmed woman. Horace's morally questionable behavior in fleeing the Curiace brothers is defended by Valère's enthusiastic description and the general delight with the victory. The same cannot be said for Horace's similarly questionable pursuit and killing of his sister.

Thus there are three cases of flight described or enacted in the fourth act of Horace: Horace flees the Curiace brothers in the first instance and his wife in the third. Between the two he does not flee, but stands, pursues, and fights. In these three encounters are examples of the four basic ethical situations pertaining to flight in the full range of Corneille's theater: 1) a male-to-male confrontation, 2) fleeing a negative, 3) a woman faced with a confrontation with a man, and 4) a confrontation between a man and a woman where there is some sentimental attachment between them. Horace transgresses the first rule; Camille follows the second and third by running from her brother's sword, but to no avail. As for the final norm, Horace is indeed justified in fleeing his wife; however, it is hardly a praiseworthy course of action unless viewed in light of his recent confrontation with Camille. It is better to flee than to kill another female family member.

Quite aside from the moral dimensions of flight in Horace there is the issue of action and movement. The structure of flight - pursuit - flight in the fourth act suggests a lurching back and forth between the two alternatives. That oscillating structure provides a reflection of Horace's profound instability at the play's denouement. ${ }^{10}$ Much physical space is covered by Horace as

${ }^{10}$ Mitchell Greenberg describes how Horace is fragmented by the experience of killing first his brothers-in-law and then his sister (287-88). 
well. He dashes off repeatedly, whether in flight or pursuit, his movements either recounted in a récit or visible onstage. This dramatic movement stands in marked contrast, first, to the women's near imprisonment onstage in act III as they and the elder Horace await the outcome of the battle and, second, to the fifth act when the arrival of the king turns the stage into a virtual courtroom where no one may move while the king presides. The back and forth between imprisonment and flight works to structure the rhythm of the play in a manner that echoes what we find in act IV with Horace's reported flight from the Curiace brothers, his onstage pursuit of his fleeing sister, and his flight from the stage and his wife. These destabilizing and at times surprising fluctuations are similar to others earlier in the play, such as Camille's moods, Sabine's stances towards the combat between husband and brothers, and even the general uncertainty concerning whether to allow the combat to go forward or not.

Beyond its structural elegance, how is one to interpret flight in the fourth act of Horace? There are several possible explanations. Horace is Corneille's first play after the querelle $\mathrm{du} \mathrm{Cid}$, during which the playwright was chastised for infractions against vraisemblance and the bienséances (among other particulars, for envisioning a marriage between Chimène and the man who killed her father). The similarities between the two plays are striking. ${ }^{11}$ Others have noted that while Corneille makes an effort in Horace to appease the doctes, in fact Horace's murder of his sister poses the same problems as Chimène's future with Rodrigue. ${ }^{12}$ While Horace's sororicide is historically true, it is far beyond the boundaries of verisimilitude that a Roman hero would commit such an unseemly act. Horace's act of flight in battle thus fits well within a reading of the play as an expression of the playwright's refusal to capitulate to the demands of his critics in the querelle. ${ }^{13}$ From another angle, Horace's inappropriate flight during his engagement with the Curiace brothers may be viewed as a harbinger of his unseemly way of dealing with his sister. It could also presage Tulle's decision to place Horace above the law. All three actions (flight, sororicide, judgment) present conduct that is outside moral and/or civic law. Corneille's delight in an oxymoronic figure

${ }^{11}$ See Philip Koch's illuminating article on the subject.

${ }^{12}$ For example, Georges Forestier points out that "le crime dénaturé d'Horace contre sa sœur avait failli provoquer une nouvelle querelle" (140). See also Merlin-Kajman (102).

${ }^{13}$ Hélène Merlin-Kajman asserts further: "Horace constitue une provocatio ad populum, une réinstruction du procès du $\mathrm{Cid}$, une présentation de la 'cause' au public. Condamné par les Académiciens, interdit de répondre à leurs 'sentiments,' Corneille fait une seconde tragédie qui constitue une sorte de récidive car une femme s'y retrouve épouse d'un parricide et la soumet au public et, comme pour Le Cid, le peuple, le succès public, lui donnent raison" (112). See also McClure (144). 
such as Horace the fleeing hero must have some place as well in any interpretation of Horace's act. Finally, from yet another standpoint, a case can be made, despite the eponym's consecrated role as a hero in Corneille's exalted tetralogy, that Horace's heroism is highly problematic. Horace is simultaneously heroic (defeating the Albans) and not at all heroic (fleeing and then killing his sister); in Merlin-Kajman's terms he is "héros vertueux et parricide, illustre et menace d'infamie" (104).${ }^{14}$ Horace stands as an embodiment of ambiguity and irregularity.

In conclusion, flight with its physical movement and emotional charge contributes to the dramatic force of Corneille's theater. More significantly, flight's moral weight offers a broader dimension, one which contains links to heroism and gender roles. Of the numerous possible explanations of the role of flight as it pertains to Horace, I find the most satisfying to be the one related to the querelle $\mathrm{du}$ Cid. As the playwright multiplies instances of flight in the play and breaks his own norms concerning the relationship between flight and heroism, he suggests that he, the dramatist, is not subject to the rules of the doctes, and that he, like Horace, can use tactical flight to evade them. The ethics of flight is suspended for superior beings.

\title{
TRINITY UNIVERSITY
}

\author{
WORKS CITED
}

Corneille, Pierre. CEuvres complètes. 3 vols. Ed. Georges Couton. Paris: Gallimard, 1980-87.

Forestier, Georges. Essai de génétique théâtrale. Paris : Klincksieck, 1996.

Greenberg, Mitchell. "Horace, Classicism and Female Trouble." Romanic Review 74.3 (1983): 271-92.

Harris, Joseph. “'Oser pleurer': Horace and the Power of Tears." Seventeenth-Century French Studies 31. 2 (2009): 163-74.

Koch, Philip. "Horace: Réponse cornélienne à la querelle du Cid." Romanic Review 76.2 (1985): 148-61.

Karsenti, Tiphaine and Alain Brunn. "Pourquoi Horace s'enfuit-il? La bienséance, rapport ou limite." Dix-septième siècle 56 (2004): 199-212.

Maskell, David. "Corneille's Examens Examined: The Case of Horace." French Studies 51 (1997): 267-80.

McClure, Ellen. "Neo-Stoicism and the Spectator in Corneille's Horace." Studies in Early Modern France 13 (2010): 144-58.

${ }^{14}$ Cinna and Polyeucte, the two "heroes" who follow Horace in Corneille's $\propto u v r e$, are also ungainly exemplars of heroism. They too are diminished by flight. Cinna, metaphorically at least, flees his commitments to his fellow conspirators, while Polyeucte quite literally repeatedly attempts to flee confrontation with Pauline (1.2; 4.1-2). 
Merlin-Kajman, Hélène. "Réécriture cornélienne du crime: le cas d'Horace." Littératures classiques 67 (2009): 101-14.

Rathé, Alice. La Reine se marie: Variations sur un thème dans l'œuvre de Corneille. Droz, 1990.

. "La Tentation du parricide dans le théâtre de Corneille." Actes de Lexington: Pierre Charron, Saint-Simon, la mort dans la littérature du XVIIe siècle. Ed. Jean Charron and Mary Lynne Flowers. Paris: PFSCL/ Biblio 17, 1995. 319-30.

Vernet, Max. "Narrar (-) la Ruse." Ecriture de la Ruse. Ed. Elzbieta Grodek. Amsterdam: Rodopi, 2000, 22-36. 
Copyright of Romance Notes is the property of University of North Carolina, Department of Romance Languages and its content may not be copied or emailed to multiple sites or posted to a listserv without the copyright holder's express written permission. However, users may print, download, or email articles for individual use. 